\title{
In vitro preliminary studies of chitooligosaccharide coated nanostructured lipidic nanoparticles for efficient gene delivery
}

\author{
Behiye ŞENEL ${ }^{1}$ \\ 1 Department of Pharmaceutical Biotechnology, Faculty of Pharmacy, Anadolu University, Eskişehir, Turkey \\ * Corresponding Author. E-mail: behiyek@anadolu.edu.tr (B.S.); Tel. +90-532-403 2095.
}

Received: 11 March 2019 / Revised: 21 May 2019 / Accepted: 26 May 2019

\begin{abstract}
Gene therapy is generally defined as the transfer of genetic material to cells to treat a disease or at least improve the clinical condition of a patient. The most commonly used vectors in gene therapy are viral and non-viral vectors. The aim of this study was to develop a gene carrier system based on chitooligosaccharide-coated nanostructured lipidic nanoparticles and evaluate the physicochemical properties, such as zeta potential, particle size, SEM images, $\mathrm{pH}$, cytotoxicity, DNA-binding properties, serum stability and transfection to cells. In this study, cationic formulations were produced using Dynasan ${ }^{\circledR} 116$ and Transcutol ${ }^{\circledR P}$ as a lipidic phase and chitooligosaccharide lactate for polymeric coating with DOTAP as a cationic agent. These formulations were made with the oil-in water hot emulsification technique. GFP was selected as the genetic material to be loaded into the formulations. According to the results, the chitooligosaccharide-coated cationic lipid nanoparticles prepared had considerably small particle sizes (144$178 \mathrm{~nm})$ and high zeta potential $(+37.6 /+33.7 \mathrm{mV})$. Based on the MTT assay, the cytotoxic effect of formulations on the NIH 3T3, A549 and MDA-MB-231 cell lines exhibited a dose-time-dependant pattern. Further, the prepared formulations binded DNA effectively and protected DNA against the serum component. It was concluded that chitooligosaccharide-coated lipidic nanoparticle formulations can be prepared as a pDNA-nanoparticle complex and can be employed as a gene delivery system effectively.
\end{abstract}

KEYWORDS: Chitooligosaccharide lactate; lipidic nanocarrier; gene delivery; cytotoxicity; transfection.

\section{INTRODUCTION}

Gene therapy is a phenomenon based on the treatment of defective genetics in specific cells by replacing or supplementing the specific gene of interest through correction of defective genes [1]. Gene therapy is carried out via two different strategies, ex vivo and in vivo gene therapy. With the ex vivo strategy, the cells taken from a patient are overhauled in the laboratory and returned to the patient, while in vivo gene therapy constitutes the therapeutic gene being injected directly into the patient. The greatest challenge is nucleic acid-based therapy, both ex vivo and in vivo, in terms of the efficient delivery of the active molecule to the cells, i.e., transfection [2]. Transfection efficiency in gene therapy is one of the most important factors for successful gene therapy. There are two types of genetic material transport systems defined to date, namely viral (retroviruses, adeno-associated virus, adeno virus, etc.) and non-viral (cationic liposomes, polymers, solid lipid nanoparticles, etc.) gene delivery systems. Although viral genetic material delivery systems feature high levels of transfection properties, they have many disadvantages, such as oncogenic effects and immunogenicity. For this reason, the use of non-viral lipidic and polymeric nanoparticles for gene delivery is increasingly of interest for medical purposes [1,2].

Solid lipid nanoparticles (SLNs) and Nanostructured lipid carriers (NLCs) are the two main classes of lipid-based nanoparticles and they have been presented as an alternative to conventional carrier systems, such as emulsion, liposome and polymeric systems from the early 1990s [3,4].

SLNs are nanometre-sized particles prepared with solid lipids at room and body temperature and they can be stabilized by surfactants. Lipids used to prepare nanoparticles are biocompatible compounds with the GRAS (Generally Recognized As Safe) feature. Triglycerides (tristearin, etc.), fatty acids (stearic acid, etc.), steroids (cholesterol etc.) and waxes (cetyl palmitate, etc.) can be employed as solid lipids [5-8].

How to cite this article: Şenel B. In vitro preliminary studies of chitooligosaccharide coated nanostructered lipidic nanoparticles for efficient gene delivery. J Res Pharm. 2019; 23(4): 671-681. 
NLC systems are the second generation of innovative lipid nanoparticles serving as bioactive carrier systems. NLCs consisting of a mixture of liquid and solid lipids have been developed to overcome some potential limitations of solid lipid nanoparticle $[9,10]$. Among the major advantages of NLCs is increased stability and drug-loading capacity, as well as preventing the discontinuation of the drug during storage [11, 12].

Chitooligosaccharides (COS) are chitosan or chitin disruption products prepared by enzymatic or chemical hydrolysis of chitosan. As mentioned in the literature, chitosan and its derivatives have valuable traits that make it possible to apply in many areas, such as food, cosmetics, biomedicine and agriculture. It is also important in the field of drug development owing to its biodegradable, non-toxic and non-allergic nature [13]. In addition, based on their highly positive electric charges, they play a major role in gene delivery [1416]. COS has a low molecular weight and is highly soluble in water because of their short chain lengths and free amino groups in their D-glucosamine units. In addition, they are readily absorbed by the human intestines. With this, oligosaccharides have recently become more and more attractive to researchers because they are biocompatible and biodegradable, like chitosans [13,17].

In this study, the aim was to develop a gene carrier system that is biodegradable, at the nanoscale and having high transfection efficiency. For this reason, nanostructured lipidic formulations with different surfactants have been prepared and coated with chitooligosaccharide. As a result, nanoparticles with low nanoparticle size, relatively high zeta potential and high transfection efficiency were prepared. As a consequence of their six-month stability, no significant change was observed in their size, zeta potential or DNA-binding properties.

\section{RESULTS AND DISCUSSION}

The application of gene therapy in various diseases has attracted attention for the last two decades. After a series of lethal events, most of which were based on the use of viral vectors and because most immunogenic reactions or mutations were caused by viruses, gene therapy has experienced a strong suppression owing to safety concerns. However, significant advances have been made thanks to technological and scientific developments, and so non-viral delivery systems have been utilised in the transport of genetic materials over the years [20].

Additionally, the FDA's approval and market launch of a variety of biological pharmaceuticals, including antibodies and genetic materials, support the potential for improvement strategies of these transport systems. Therefore, the formulation of transport systems for biological molecules has become an important area. In this study, we leveraged the advantages of NLC systems and the natural cationic properties of chitosan to develop a more efficient gene delivery system.

\subsection{Characterisation studies}

Physicochemical properties, such as particle size, size distribution, shape, solubility and surface charge, factor prominently in biological processes, including biodistribution, toxicity and cellular uptake of nanoparticles [21].

Nanoparticle size and size distribution was determined by dynamic light scattering with a particle size analyser (Malvern Zeta Sizer Nano ZS) at a constant angle of $175^{\circ}$ at $25^{\circ} \mathrm{C}$. Size distribution was established through the polydispersity index. The smaller these values were evaluated, the narrower the size distribution or the uniformity of the prepared nanoparticles. The data on particle size, size distribution (PDI), pH and zeta potential are reported in Table 1, representing the average of three measurements. During preliminary studies of the formulations, particle sizes between $255-523 \mathrm{~nm}$ were determined before filtration. It was noted that small particle size increases stability and decreases toxicity [22].

Therefore, filtering was effective in reducing these dimensions. So, the particle sizes of the prepared formulations were below $200 \mathrm{~nm}$. The particle distribution in the dispersion was also assessed as relatively homogeneous.

The debate surrounding the optimum size required for cellular uptake in the literature is still ongoing. In one study, it was stated that a particle size of 100-500 nm was optimal for lymphatic uptake via the GI lymphatic system, but smaller particles were slow to receive [23]. It has been put forth that nanoparticles with a diameter of $100 \mathrm{~nm}$ engage in cellular uptake 2.5-fold greater than 1-micron diameter particles in Caco-2 
cells [24]. In another investigation, it was stated that 50-nm nanoparticles were more efficiently internalized and had a higher uptake rate whereas there was a decreased cellular uptake for smaller or larger particles [25]. Cell type is also significant in the recruitment of nanoparticles. For example, in hepatic cell lines, such as Hep G2 and Hepa 1-6, nanoparticles between 93 and $220 \mathrm{~nm}$ dimensions can be internalized, while much larger particles, up to 1 micron, are effectively internalized by HUVEC, HNX 14C and ECV 30 cell lines [26]. In this study, the particle sizes of all formulations were in the range of $115 \pm 1.3$ and $189 \pm 0.55 \mathrm{~nm}$. Most researchers recognize PDI values $\leq 0.3$ as optimum values; however, values $\leq 0.5$ are also acceptable. For polydisperse systems, the PDI should be less than 0.5. The PDI value of all formulations ranged between $0.115 \pm 0.12$ and $0.301 \pm 0.05$ (Table 1), indicating that the formulations are polydisperse systems with relatively homogenous size distributions.

Table 1. Results of particle size, polydispersity index and zeta potential for prepared formulations. Standard errors were indicated as \pm in the table.

\begin{tabular}{lcccc}
\hline & Particle size $(\mathbf{n m})$ & PDI & Zeta potential $(\mathbf{m V})$ & $\mathbf{p H}$ \\
\hline F1 & $115 \pm 1.3$ & $0.158 \pm 0.05$ & $-28.2 \pm 4.06$ & $6.5 \pm 0.2$ \\
F2 & $152 \pm 2.7$ & $0.222 \pm 0.1$ & $-20.3 \pm 3.3$ & $6.0 \pm 0.4$ \\
F1/COS & $144 \pm 2.5$ & $0.115 \pm 0.12$ & $+37.6 \pm 2.8$ & $6.5 \pm 0.5$ \\
F2/COS & $178 \pm 3.7$ & $0.178 \pm 0.21$ & $+33.7 \pm 1.6$ & $5.8 \pm 0.3$ \\
F1/COS/DNA & $167 \pm 0.77$ & $0.229 \pm 0.03$ & $+33.8 \pm 2.1$ & $6.5 \pm 0.4$ \\
F2/COS/DNA & $189 \pm 0.55$ & $0.301 \pm 0.05$ & $+29 \pm 1.8$ & $5.8 \pm 0.5$ \\
\hline
\end{tabular}

The zeta potential is the measure of the total loads obtained by particles in a given environment and is the second main characterisation tool to assist in understanding formulation stability. In the literature, if the zeta potential is above $30 \mathrm{mV}$, it is notable that the distribution system provides robust stability, whereas below $30 \mathrm{mV}$, it leads to instability [27, 28]. In transporting the genetic material, it is necessary to create an electrostatic interaction between the pDNA and particles. So, nanoparticles should have a specific zeta potential and therefore be capable of binding to the cell membrane as a result of it [29,30]. According to the zeta analysis results, it was determined that those particles coated with COS have a suitably high zeta potential values and stability for interactions with cell membranes.

The morphology of the particles was analysed using SEM. When reviewing the SEM images, prepared COS-coated formulations had spherical particles featuring rough as well as smooth surfaces (Figure 1).
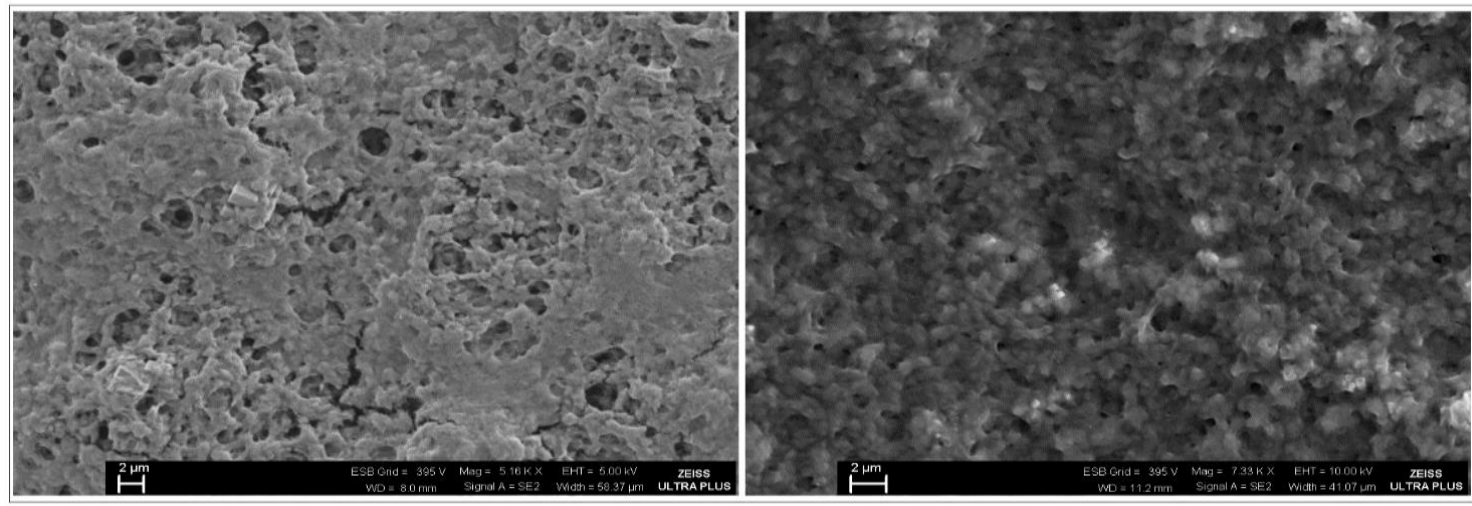

Figure 1. The SEM images of F1 /COS (left) and F2/COS (right).

\subsection{Gel Retardation Assay}

The gel retardation studies were performed for controlling DNA-nanoparticle interactions and learning the effects of serum and DNAse. Understanding the interaction of DNA/nanoparticles with physiological fluids is critical to their use for in vivo delivery. The amount and size of the genetic material, the coating material of the carrier system used or the adsorption/encapsulation of genetic material are important parameters for protection against DNAse endonucleases [31].

DNA-binding properties of F1/COS and F2/COS formulations were established using gel documentation systems. For this reason, $0.5 \mu \mathrm{g}$ pGFP DNA and between $0.05-2 \% \mathrm{w} / \mathrm{w}$ concentration ratios 
were used. The complexes were observed on the gel after incubation for $15 \mathrm{~min}$ at $37^{\circ} \mathrm{C}$ to attain electrostatic interactions. It was observed that the formulations could bind effectively at all studied concentrations.

As it can be seen in Figure 2, the high positive charges of COS-coated formulations appear to neutralize the negative charges of phosphate groups in the DNA backbone, thereby inhibiting the movement of DNA from the well. It is obvious that lipidic nanoparticles have a negative charge unless a cationic lipid is added or coated with a positive charge, such as that with chitosan. Therefore, no binding studies were carried out on them in this study.

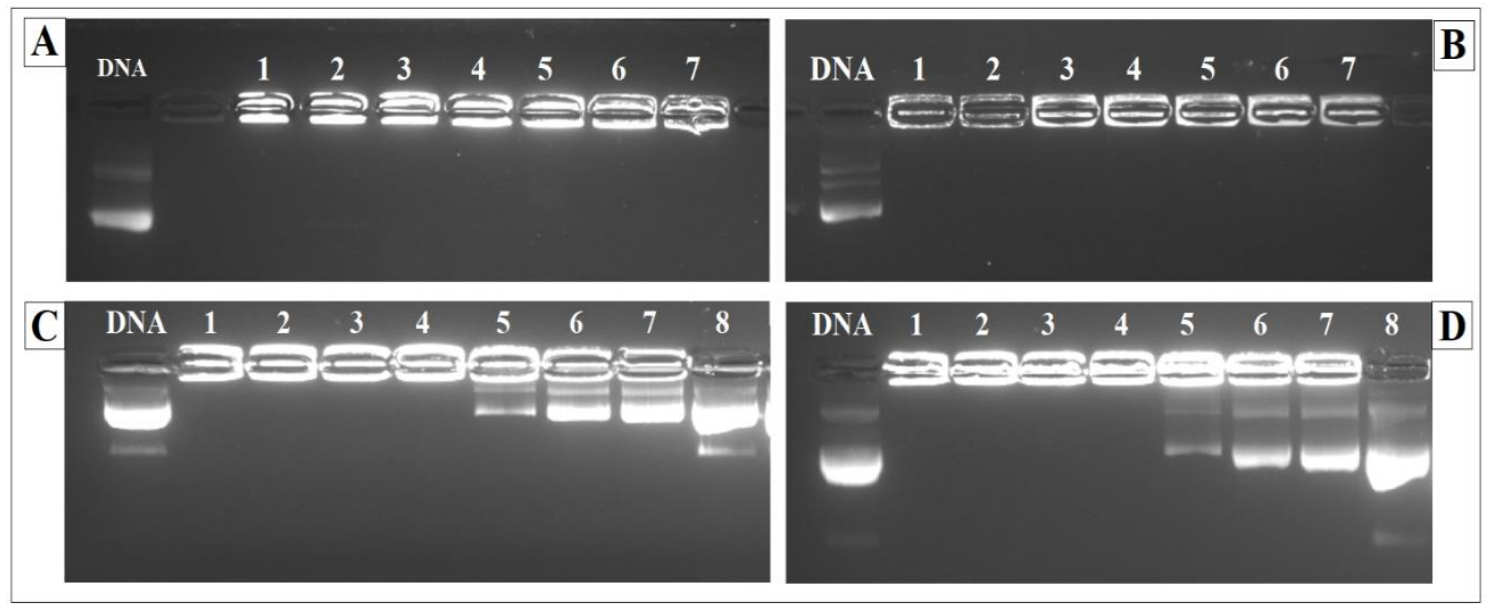

Figure 2. Agarose gel electrophoresis results of all formulations. DNA binding properties of F1/COS (A) and F2/COS (B). First well contains $0.5 \mu \mathrm{g}$ pGFP DNA. The nanoparticle/DNA ratios are as follows (w/w \%) . Lane 1: 0.05/0.5, Lane 2: 0.075/0.5, Lane 3: 0.1/0.5, Lane 4: 0.25/0.5, Lane 5: 0.5/0.5, Lane 6: 1/0.5 Lane 7: 2/0.5. The effect of serum component on formulations F1/COS (C) and F2/COS (D). First well contains 1 $\mu \mathrm{g}$ pGFP DNA. Lane 1-8 are 0, 1, 2, 3, 6, 12, 24 and 48-hour time intervals, respectively.

In vivo administration of naked DNA is not possible owing to cleavage by nucleases in blood circulation. Thus, the formulations prepared should protect DNA against both serum components (lipases, high density lipoproteins, etc.) and nucleases [32,33].

When the F1/COS/DNA and F2/COS/DNA were treated with $10 \%$ serum, the complexes began to dissociate in very small amounts at six hours onwards with almost complete dissociation after 48 hours (Figure $2 \mathrm{C}$ and 2D).

\subsection{Cell viability and transfection}

Nanoparticulate systems are necessary for gene transport, but these systems cannot be used if the genetic material is not able to enter the cell or be released effectively. As the size of the developed particles becomes smaller, the ratio of surface area to volume rises. This means that the drug is closer to the particle surface of a small molecule than a large molecule. Being on or near the surface will lead to faster drug release [23]. The formulation of nanoparticle systems with a large surface area/volume ratio is hence very important. However, as size may affect cytotoxicity, optimum properties should be determined [20, 34].

In vitro cell viability and transfection efficacy analysis were carried out in NIH-3T3, A549 and MDA-MB 231 cells, in particular with both normal and cancer cell types. The reason for this was to reveal the possible differences in cell viability or transfection and how this affects such cells. As can be seen in Figure 3, the cell viabilities of formulations exhibited dose- and time-dependent patterns compared with controls.

The formulations without COS coating were identified as the most effective on cells. F1 formulations also influenced cell viability at lower doses than F2 ( $<<0.1)$. At the end of a 24-hour incubation period, the IC 50 values for $100 \mu \mathrm{L}$ were observed as $17 \mu \mathrm{g} \pm 2.2,20 \mu \mathrm{g} \pm 3.2$ and $17 \mu \mathrm{g} \pm 4.3$ for F1 and $27 \mu \mathrm{g} \pm 1.8,33 \mu \mathrm{g} \pm 2.1$ and $58 \mu \mathrm{g} \pm 0.6$ for F2 formulations in 3T3, A549, MDA-MB cells, respectively. At the end of a 48-hour incubation period, the $\mathrm{IC}_{50}$ values for $100 \mu \mathrm{L}$ were observed as $14 \mu \mathrm{g} \pm 3.3,16 \mu \mathrm{g} \pm 2.0$ and $20 \mu \mathrm{g} \pm 3.1$ for F1 and $15 \mu \mathrm{g} \pm 1.6,19 \mu \mathrm{g} \pm 2.7$ and $20 \mu \mathrm{g} \pm 3.5$ for F2 formulations.

When examining COS-coated formulations, the $\mathrm{IC}_{50}$ values for $100 \mu \mathrm{L}$ were observed at $24 \mu \mathrm{g} \pm 1.5,48$ $\mu \mathrm{g} \pm 2.7$ and $50 \mu \mathrm{g} \pm 3.9$ for F1/COS and $55 \mu \mathrm{g} \pm 2.2,55 \mu \mathrm{g} \pm 5.7$ and $63 \mu \mathrm{g} \pm 2.6$ for F2/COS formulations in $3 \mathrm{~T} 3, \mathrm{~A} 549$, MDA-MB cells, respectively. Moreover, at the end of the 48 -hour incubation, the $\mathrm{IC}_{50}$ values for 100 
$\mu \mathrm{L}$ were observed as $15 \mu \mathrm{g} \pm 4.4,30 \mu \mathrm{g} \pm 3.8$ and $35 \mu \mathrm{g} \pm 1.6$ for F1/COS and $30 \mu \mathrm{g} \pm 6.6,32 \mu \mathrm{g} \pm 3.5$ and $50 \mu \mathrm{g}$ \pm 3.4 for F2/COS formulations.

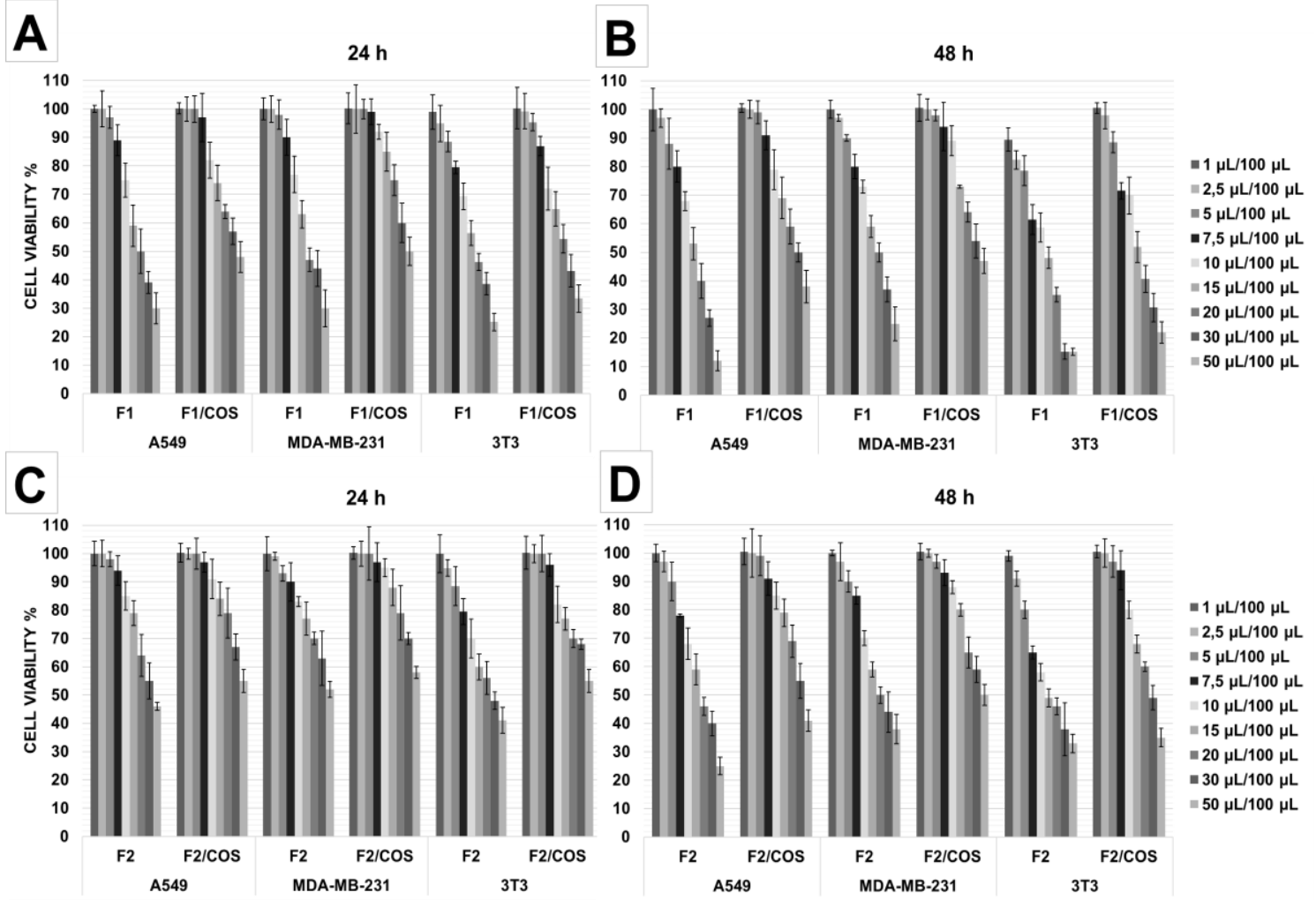

Figure 3. The cell viability results of F1, F1/COS, F2 and F2/COS formulations on 3T3, A549 and MDA-MB231 cell lines for 24 and $48 \mathrm{~h}$ incubation times.

One of the most important obstacles to preparing successful genetic material-loaded nanoparticles was ensuring they reach the target and exhibit effectiveness. When compared with lipofectamine 2000/GFP, F1/COS/pGFP and F2/COS/pGFP had almost similar transfection efficiencies at 24 hours (Figure 4). According to the results, it was found there was $75 \%, 69 \%$ and $79 \%$ transfected cells for lipofectamine 2000, F1/COS and F2/COS for 3T3 cells, respectively. Further, there was $81 \%, 70 \%$ and $75 \%$ transfection for A549 cells while $76 \%, 68 \%$ and $77 \%$ for MDA-MB-231 cells with lipofectamine 2000, F1/COS and F2/COS, respectively. There were no statistically significant differences between these results $(p>0.05)$. 

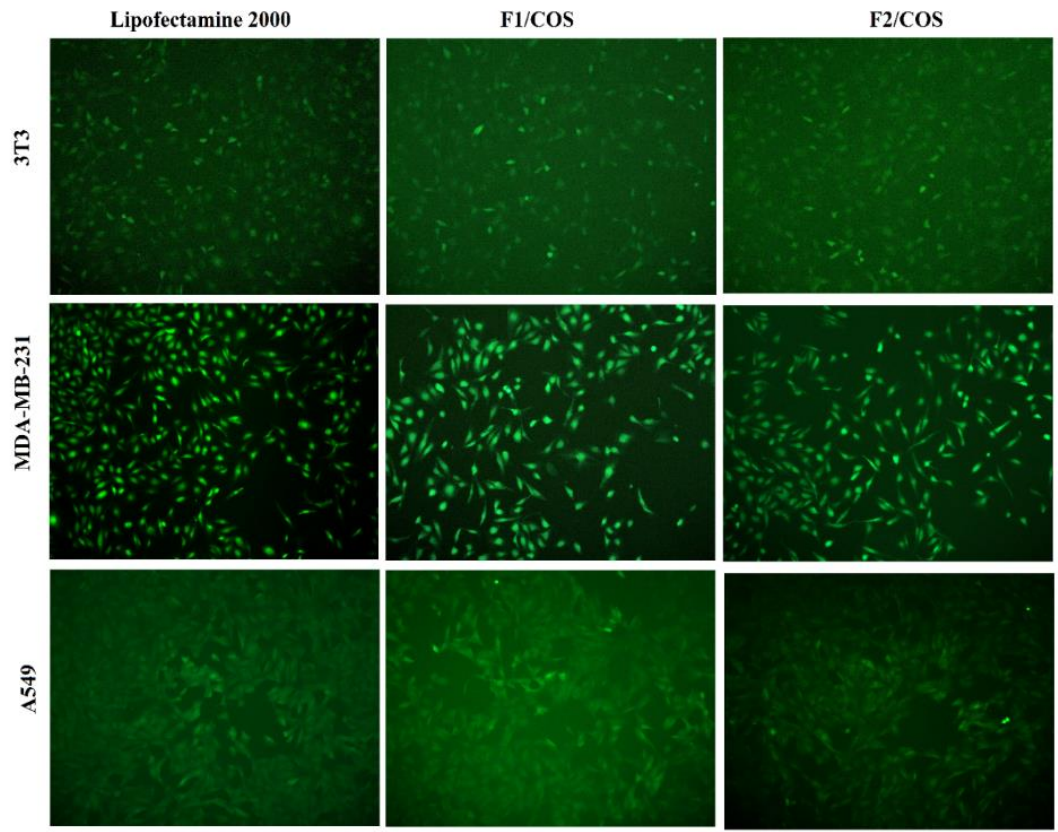

Figure 4. Fluorescence images of formulations and Lipofectamine ${ }^{\circledR} 2000$ on cells at $24 \mathrm{~h}$.

The hydrophilicity of molecules also impacts cellular uptake. For example, hydrophobic nanoparticles have rapid clearance owing to their greater interaction with blood components, whereas the high hydrophilicity of nanoparticles decreases clearance by preventing hepatic and kidney localisation. Therefore, it is important to cover nanoparticles with polymers and surfactants [23]. Ultimately, it was observed that our formulations are suitable for the aforementioned transfection process - the complexes delivered DNA more easily into cells.

\subsection{Stability studies}

Stability studies were carried out at $30 \pm 2{ }^{\circ} \mathrm{C} / 65 \pm 5 \% \mathrm{RH}$ for a period of six months. The mean particle size, polydispersity index, zeta potential and DNA-binding capacity of the formulations were determined as a function of storage time. The results of these observations were presented in Table 2 and Figure 5.

Table 2. The results of particle size, polydispersity index and zeta potential measurements of formulations, after 0,3 and 6 months time intervals. Standard error was indicated as \pm in the table.

\begin{tabular}{llllllllll}
\hline & \multicolumn{3}{c}{ Particle Size (nm) } & \multicolumn{3}{c}{ Polydispersity Index (PDI) } & \multicolumn{3}{c}{ Zeta Potential (mV) } \\
\hline Mounths & 0 & 3 & 6 & 0 & 3 & 6 & 0 & 3 & 6 \\
F1/COS & 144 & 365 & 589 & 0.115 & 0.301 & 0.425 & +37.6 & +31.6 & +29.8 \\
& \pm 2.5 & \pm 3.1 & \pm 1.7 & \pm 0.12 & \pm 0.02 .5 & \pm 5.2 & \pm 2.8 & \pm 2.5 & \pm 3.3 \\
F2/COS & 178 & 188 & 221 & 0.178 & 0.150 & 0.111 & +33.7 & +32.5 & +31.5 \\
& \pm 3.7 & \pm 1.2 & \pm 2.2 & \pm 0.21 & \pm 0.15 & \pm 1.3 & \pm 1.6 & \pm 0.5 & \pm 1.1 \\
\hline
\end{tabular}

According to the results, it was observed that there was no significant difference in particle size, PDI and DNA-binding activity of F2/COS nanoparticles stored for 60 days. However, for the F1/COS formulations, the particle size and polydispersity index increased. Nevertheless, DNA-binding capacity did not become reduced. At the end of six months, no visible changes were observed in F2/COS while the F1/COS formulations were present in an agglomeration at the bottom of the tube that could be dispersed via simple shaking. Considering that the only difference between the two formulations is the surfactants used, it was concluded that the surfactants employed have an effect on the characterisation properties of the particle during storage. 


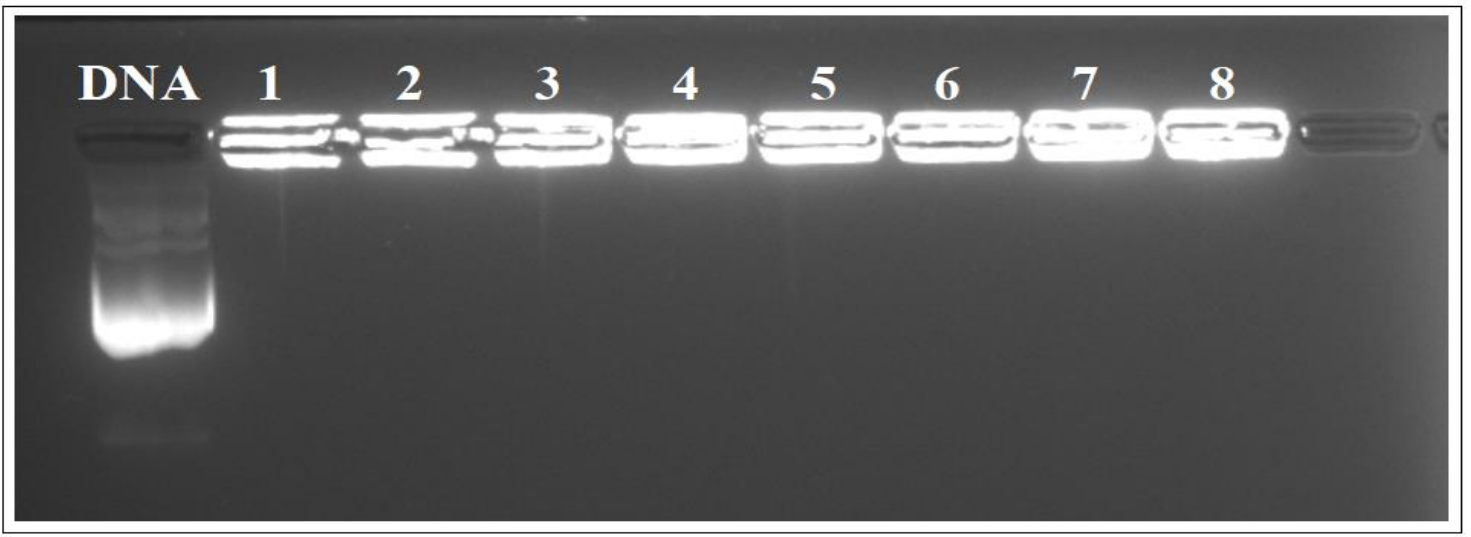

Figure 5. The results of DNA binding properties of formulations, after 6 months. First well contains $0.5 \mu \mathrm{g}$ pGFP DNA. Lane 1-4 for F1/COS and Lane 5-8 for F2/COS, shows the DNA binding activity at 0.05/0.5; $0.1 / 0.5 ;: 0.5 / 0.5 ; 2 / 0.5$ ratios, respectively.

In the literature, the importance of surfactants in nanoparticle decorations [35], the reduction of particle size [36], preservation of stability [37] and the significance of preventing coalescence [38] are indicated. In our study, the effect of the surfactant is clearly evident.

\section{CONCLUSION}

Lipid systems, which can be prepared with solid or liquid lipids, are rapidly gaining researchers' attention thanks to their potential. As a consequence of their ease of use and efficiency, the addition of biodegradable polymeric systems, such as chitosan, increases the availability of these delivery systems. It also reduces the cytotoxicity of lipidic structures. In this study, chitooligosaccharide lactate-coated lipidic nanoparticle dispersions with small particle size and long-term physical stability were successfully prepared using a hot emulsification technique. We believe that the formulations prepared herein are promising carrier systems with relatively small particle sizes, high zeta potentials, effective DNA-binding rates and robust transfection properties for genetic materials that can be applied to the treatment of a wide range of generelated diseases, such as cancers, hereditary diseases and infectious diseases.

\section{MATERIALS AND METHODS}

Chitooligosaccharide lactate (Cat no: 523682) was used as polymer and were purchased from Sigma Aldrich (Germany). Dynasan ${ }^{\circledR} 116$ from IOI Oleo GmbH and Transcutol ${ }^{\circledR P}$ from Gattefosse (France) were kind gift. As a surfectants, $\operatorname{Span}^{\circledR} 60$ (Cat no: 7010) and PF127 (Cat no:2443) were obtained from Sigma Aldrich (Germany), Span ${ }^{\circledR} 80$ (Cat no:85548) was obtained from Fluka (Germany), and Tween ${ }^{\circledR} 20$ (Cat no:817072) was obtained from Merck (Darmstadt, Germany). gWiz-GFP plasmid (Cat no: 90659) for transfection was purchased from Aldevron (North Dakota, USA). Lipofectamine ${ }^{\circledR} 2000$ (Cat no: 116-68) used as the reference transfection agent was supplied by Invitrogen (Paisley, UK). DMEM (Cat no: D5796), fetal bovine serum (Cat no:F4135), agarose (Cat no:9539), Penicillin and streptomycin solution (Cat no: P4333), tyripsin/EDTA solution (Cat no: T4049), and ethidium bromide (Cat no: E1510) were obtained from Sigma Aldrich (Germany). Ultrapure water was obtained using a MilliQ system (Millipore, Bedford, MO, USA). The ultrapure water used in all studies was used after autoclaved.

\subsection{Preparation of the LNPs}

Lipid nonoparticles (LNPs) were prepared by using oil-in water hot emulsification technique, with some modifications [39]. In this technique, weighed amount of solid lipid (Dynasan $\left.{ }^{\circledR} 116\right)$ and liquid lipid (Transcutol ${ }^{\circledR} \mathrm{P}$ ) were heated to the temperature of $10^{\circ} \mathrm{C}$ above the melting point of solid lipid $\left(\sim 70^{\circ} \mathrm{C}\right)$, and the molten lipid was dispersed in the hot surfactant solution (Tween ${ }^{\circledR 20}$, Span ${ }^{\circledR 80}$, Span ${ }^{\circledR} 60$, Pluronic ${ }^{\circledR}$ F127) of the same temperature by high-speed stirring at $15.000 \mathrm{rpm}$ using an Ultra Turrax (IKA T-25, USA), and further homogenized for $5 \mathrm{~min}$. The hot dispersion was filtered through a 0.22 non pyrogenic filter. Ratios of formulations prepared are shown in Table 3. 
Table 3. The ratios of components in prepared formulations.

\begin{tabular}{|c|c|c|c|c|c|c|}
\hline & $\begin{array}{c}\text { Dynasan }{ }^{\circledR 116} \\
(w / w \%)\end{array}$ & $\begin{array}{c}\text { Transcutol }{ }^{\circledR P} \\
(w / w \%)\end{array}$ & $\begin{array}{c}\text { Tween }^{\circledR} 20 \\
\text { (w/w\%) }\end{array}$ & $\begin{array}{c}\operatorname{Span}^{\circledR} 80 \\
\left(\mathbf{w} / w^{0} \%\right)\end{array}$ & $\begin{array}{c}\operatorname{Span}^{\circledR} 60 \\
(w / w \%)\end{array}$ & $\begin{array}{c}\text { PF127 } \\
\left(w / w^{0} \%\right)\end{array}$ \\
\hline F1 & 0.8 & 0.7 & 0.8 & 0.8 & - & - \\
\hline F2 & 0.8 & 0.7 & - & - & 0.8 & 0.8 \\
\hline
\end{tabular}

\subsection{Coating with COS of LNPs}

For the preparation of chitooligosaccharide (COS) coated LNPs, $2.5 \mathrm{~mL}$ of the previously prepared and lipidic formulation was slowly added to $10 \mathrm{~mL}$ of COS solution $4 \%$ (w/v) (in 1xPBS) under magnetic stirring via drop-wise carefully. The droplets were dropped with a $1000 \mu \mathrm{L}$ micropipette in 2.5 minutes at $500 \mathrm{rpm}$. The mixture was further stirred for 1 hour. The formulations were centrifuged for $10 \mathrm{~min}$ at $8000 \mathrm{rpm}$ to remove the free COS from formulation. Supernatants were carefully removed and pellets were redispersed in autoclaved distilled water.

The obtained lipid nanoparticles uncoated and COS coated LNPs were stored in sealed containers at room temperature and $30^{\circ} \mathrm{C}$ for further analyses. The prepared formulations were named as F1/COS and F2/COS.

\subsection{Characterization of the LNP's and coated LNP's}

\subsubsection{Particle size and zeta potential}

Particle size, the particle size distribution via the polydispersity index (PI) and zeta potential was analysed by a Zetasizer NanoZS (Malvern Instruments, UK). The measurements were carried out using a suspension of the nanoparticles in $50 \mu \mathrm{S}$ distilled water. All measurements were determined in triplicates and the average values were considered [30].

\subsection{2. $\mathrm{pH}$ measurement}

$\mathrm{pH}$ value of formulations was measured with ThermoScientific Orion Star $\mathrm{pH}$ meter (USA) at room temperature [19].

\subsubsection{Adsorption of plasmid to cLNPs}

Specific amounts of GFP were mixed with cationic COS coated LNPs. Those complexes were then incubated at $37^{\circ} \mathrm{C}$ for 20 minutes to maintain electrostatic interaction between GFP and positively charged particles. GFP binding properties were visualised with gel retardation assay [19,30].

\subsection{Gel Retardation Assay}

Gel retardation studies were used to determine GFP binding efficiency to formulations and the possible degradation in serum, and also to observe adsorbtion efficiency for at the end of 6 months. Samples were loaded on a 1,5\% agarose gel with ethidium bromide staining and electrophoresis was performed for $2 \mathrm{~h}$ at $50 \mathrm{~V}$ with Tris/Acetate/EDTA (TAE) buffer. The bands properties on the gel was evaluated using a gel documentation system (Uvitec Alliance 4.7, Cambridge, UK) [19].

\subsubsection{Stability in serum}

Aiming for the maximum efficiency in cells, formulations prepared must protect GFP against the serum components and also nucleases. Therefore, formulation containig GFP were incubated at $37^{\circ} \mathrm{C}$ for $1,4,10,24$ and $48 \mathrm{~h}$ with Dulbecco's Modified Eagle Medium (DMEM) which contained $10 \%$ Fetal Bovine Serum (FBS). Images of samples were taken using a gel retardation assay at the end of the period. At the end of the time intervals, samples were loaded to 1,5\% agarose gel for 1 hour at 75 volts. Images were obtained using a gel documentation system (Uvitec Alliance 4.7, Cambridge, UK) [19].

\subsection{Scanning electron microscope characterization}

COS coated formulations analysed by ZEISS Ultra Plus Scanning Electron Microscopy (SEM) for morphological properties. Briefly, the formulations suspended in water and applied it to carbon-coated SEM 
stabs, was dried it in the air. Afterward, the stub containing the sample was coated with the gold film at $45 \mathrm{~s}$ under $30 \mathrm{~mA}$ and placed into the scanning electron microscopy (SEM) Chamber. The photos were taken at acceleration voltage of $5 \mathrm{kV}$.

\subsection{Stability studies}

Stability studies of the DNA-free formulations were performed for 6 months. The samples were evaluated for the intermediate stability studies in accordance with the $\mathrm{ICH}$ guidelines. Fort his purpose, the samples were kept at $30^{\circ} \mathrm{C} \pm 2{ }^{\circ} \mathrm{C}$ temperatures and $65 \pm 5 \%$ relative humidity for a period of 180 days stability of the all formulations was monitored periodically time periods, i.e. 0, 30, 90, and 180 days, evaluating aggregation or phase separation, DNA binding efficiency, particle size and zeta potential [18].

\subsection{Cell culture}

NIH-3T3 (mouse embryo fibroblast), A549 (human lung adenocarcinoma) and MDA-MB-231 (human breast adenocarcinoma) cells were maintained in DMEM supplemented with $10 \%$ fetal bovine serum (FBS) and $1 \%$ antibiotic [streptomycin $(100 \mu \mathrm{g} / \mathrm{mL}) /$ penicillin $(100 \mathrm{IU} / \mathrm{mL})$ ] . Cells were grown at $37^{\circ} \mathrm{C}$ with $5 \%$ $\mathrm{CO}_{2}$ in air and subcultured.

\subsubsection{Cell viability assay}

The cell viability effects of our formulations were determined. Therefore, colorimetric MTT method was used for the quantitative determination of cell viability [40]. NIH-3T3, A549 and MDA-MB-231 cells were used in the method. Absorbance of the plate was measured at $570 \mathrm{~nm}$ using a spectrometric microplate reader (BioTek, Cytation 5, England). Analyses were repeated in triplicate. Only cell culture medium contain wells were used as a control. Results were expressed as the percentage of inhibition compared to control cells where cell survival was presumed $100 \%$ [19].

\subsubsection{In vitro transfection efficiency measurement}

For the cellular uptake study, cells in a 6-well plate were seeded with antibiotic free medium and incubated at $37^{\circ} \mathrm{C}$ for $24 \mathrm{~h}$, with $5 \% \mathrm{CO}_{2}$ incubator. After reaching the desired cell density $(70-90 \%)$, formulations containing $1 \mu \mathrm{g}$ lipid in total were mixed with pGFP $(2.5 \mu \mathrm{g})$, then the composed complex mixed with antibiotic/FBS-free medium, and added to each well. After 24 hour incubations, plates were examined under a fluorescent microscope. Transfection efficacy of formulations were compared with Lipofectamine ${ }^{\circledR}$ 2000. A total of about 10000 cells (transfected and non-transfected) at each 20 different areas in the wells were counted. Transfection index (TI) was calculated using the following equation (Eq. 1) [19];

$$
\boldsymbol{T I}(\%)=\frac{\text { No.of Transfected cell }}{\text { No.of transfected cell+No.of non-transfected cell }} \times 100
$$

\subsection{Statistical analyses}

The data of MTT assay was presented as mean and standard deviation on the graphic. The differences between the treated groups and the control groups were analysed from concentration-effect-time curves using linear regression analysis with Minitab 18.and $p$ value less than 0.05 was considered statistically significant.

Acknowledgements: I greatly appreciate to Associate Professor Recep Sulhi ÖZKÜTÜK for the SEM analyses from Eskişehir Technical University. I would like to thank to Associate Professor Gülay BÜYÜKKÖROĞLU for her valuable scientific contribution.

Author contributions: Concept - B.Ş.; Design - B.Ş.; Supervision - B.Ş.; Materials - B.Ş.; Data Collection and/or Processing - B.Ş.; Analysis and/or Interpretation - B.Ş.; Literature Search - B.Ş.; Writing - B.Ş.; Critical Reviews - B.Ş.

Conflict of interest statement: The author declared no conflict of interest.

\section{REFERENCES}

[1] Bhatia S. Chapter 3: Chitosan based nanomaterials and its applications. In: Systems for Drug Delivery: Safety, Animal and Microbial Polysaccharides. Springer, Netherland, 2016, pp. 55-117. [CrossRef]

[2] Pozo-Rodríguez A, Solinís MA, Rodríguez-Gascón A. Applications of lipid nanoparticles in gene therapy. Eur J Pharm Biopharm. 2016; 109: 184-193. [CrossRef] 
[3] Souto EB, Wissing SA, Barbos CM, Müller RH. Development of a controlled release formulation based on SLN and NLC for topical clotrimazole delivery. Int J Pharm. 2004; 278: 71-77. [CrossRef]

[4] Patidar A, Thakur DS, Kumar P, Verma J. A review on novel lipid based nanocarriers. Int J Pharm Sci. 2010; 2(4): 30 5 .

[5] Demirel M, Yazan Y. Katı lipit nanopartiküller (SLN). FABAD, J Pharm Sci. 2000; 25: 167-179.

[6] Mehnert W, Mäder K. Solid lipid nanoparticles: Production characterization and applications. Adv Drug Deliver Rev. 2001; 47: 165-196. [CrossRef]

[7] Saupe A, Rades T. Chapter 3: Solid lipid nanoparticles. In: Mozafari, M.R. (Ed) Nanocarrier Technologies, Frontiers of Nanotherapy; Springer, Netherland, 2006, pp. 41-43.

[8] Numanoğlu U, Tarımcı N. Katı lipid nanopartiküllerin (SLNTM) özellikleri, farmasötik ve kozmetik alandaki uygulamaları. Ankara Ecz Fak Derg. 2006; 35(3): 211 - 235.

[9] Tamjidi F, Shahedi M, Varshosaz J, Nasirpour A. Nanostructured lipid carriers (NLC): A potential delivery system for bioactive food molecules. Innov Food Sci Emerg Tech. 2013; 19(0): 29-43. [CrossRef]

[10] Kaur S, Nautyal U, Singh R, Singh S, Devi A. Nanostructure Lipid Carrier (NLC): the new generation of lipid nanoparticles. Asian Pac J Health Sci. 2015; 2(2): 76-93.

[11] Pardeike J, Hommoss A, Müller RH, Lipid nanoparticles (SLN, NLC) in cosmetic and pharmaceutical dermal products. Int J Pharm. 2009; 366(1-2): 170-84. [CrossRef]

[12] Beloqui A, Solinís MÁ, des Rieux A, Préat V, Rodríguez-Gascón A. Dextran-protamine coated nanostructured lipid carriers as mucus-penetrating nanoparticles for lipophilic drugs. Int J Pharm. 2014; 468(1-2): 105-11. [CrossRef]

[13] Lodhi G, Kim YS, Hwang JW, Kim SK, Jeon YJ, Je JY, Ahn CB, Moon SH, Jeon BT and Park PJ. Chitooligosaccharide and its derivatives: Preparation and biological applications. Biomed Res Int. 2014; 2014: 1-13. [CrossRef]

[14] Park PJ, Je JY, Kim SK. Free radical scavenging activity of chitooligosaccharides by electron spin resonance spectrometry. J. Agric. Food Chem. 2003; 51 (16): 4624-4627. [CrossRef]

[15] Feng J, Zhao L, Yu Q. Receptor-mediated stimulatory effect of oligochitosan in macrophages. Biochem Bioph Res. Co. 2004; 317(2): 414-420. [CrossRef]

[16] Huang R, Mendis E, Rajapakse N, Kim SK. Strong electronic charge as an important factor for anticancer activity of chitooligosaccharides (COS). Life Sci. 2006; 78(20): 2399-2408. [CrossRef]

[17] Ouyang QQ, Zhao S, Li SD, Song C. Application of chitosan, chitooligosaccharide, and their derivatives in the treatment of Alzheimer's disease. Mar Drugs. 2017; 15(11): 1-15. [CrossRef]

[18] Soma D, Attari Z, Reddy MS, Damodaram A, Koteshwara KBG. Solid lipid nanoparticles of irbesartan: preparation, characterization, optimization and pharmacokinetic studies. Braz J Pharm. Sci. 2017; 53(1): 1-10. [CrossRef]

[19] Şenel B, Büyükköroğlu G and Yazan Y. Solid lipid and chitosan particulate systems for delivery of siRNA. Pharmazie, 2015; 70: 698-705.

[20] Baghdan E, Pinnapireddy SR, Strehlow B, Engelhardt KH, Schäfer J, Bakowsky U. Lipid coated chitosan-DNA nanoparticles for enhanced gene delivery. Int J Pharm. 2018; 535(1-2): 473-479. [CrossRef]

[21] Honary S, Zahir F. Effect of zeta potential on the properties of nano-drug delivery systems - a review (part 1), Trop J Pharm Res. 2013; 12 (2): 255-264. [CrossRef]

[22] Heydenreich AV, Westmeier R, Pedersen N, Poulsen HS, Kristensen HG. Preparation and purification of cationic solid lipid nanospheres effects on particle size physical stability and cell toxicity. Int J Pharm. 2003; 254: 83-87. [CrossRef]

[23] Rizvi SAA, Saleh AM. Applications of nanoparticle systems in drug delivery technology. Saudi Pharm J. 2018; 26(1): 64-70. [CrossRef]

[24] Gratton SE, Ropp PA, Pohlhaus PD, Luft JC, Madden VJ, Napier ME, Desimone JM. The effect of particle design on cellular internalization pathways. Proc Natl Acad Sci U S A. 2008; 105: 11613-11618. [CrossRef]

[25] Foroozandeh P, Aziz A. Insight into cellular uptake and intracellular trafficking of nanoparticles. Nanoscale Res Lett. 2018; 13: 339. [CrossRef]

[26] Prabha S, Arya G, Chandra R, Ahmed B, Nimesh S. Effect of size on biological properties of nanoparticles employed in gene delivery. Artif Cells Nanomed Biotechnol. 2016; 44 (1): 83-91. [CrossRef] 
[27] Komatsu H, Kitajima A, Okada S. Pharmaceutical characterization of commercially available intravenous fat emulsions: Estimation of average particle size, size distribution and surface potential using photon correlation spectroscopy. Chem Pharm Bull. 1995; 43: 1412-5.

[28] Shi L, Li Z, Yu L, Jia H, Zheng L. Effects of surfactants and lipids on the preparation of solid lipid nanoparticles using double emulsion method. J Dispers Sci Technol. 2011; 32: 1-9. [CrossRef]

[29] Zhdanov RI, Podobed OV, Vlassov VV. Cationic lipid DNA complexeslipoplexes for gene transfer and therapy. Bioelectroch. 2002; 58(1): 53-64. [CrossRef]

[30] Büyükköroğlu G. Development of solid lipid nanoparticles as gene delivery system, Turk J Pharm Sci. 2016; 13(2): 169-181. [CrossRef]

[31] lbanese A, Tang PS, Chan WCW. The effect of nanoparticle size, shape, and surface chemistry on biological systems. Annu Rev Biomed Eng. 2012; 14(1):1-16. [CrossRef]

[32] Rao NM. Cationic lipid-mediated nucleic acid delivery: Beyond being cationic. Chem Phys Lipids. 2010; 163: 245252. [CrossRef]

[33] Kumari M, Liu CH, Wu WC. Efficient gene delivery by oligochitosan conjugated serum albumin: Facile synthesis, polyplex stability, and transfection. Carbohydr Polym . 2018; 183(1): 37-49. [CrossRef]

[34] Han Y, Li Y, Zhang P, Sun J, Li X, Sun X, Kong F, Nanostructured lipid carriers as novel drug delivery system for lung cancer gene therapy. Pharm Dev Technol. 2016; 21(3): 277-81. [CrossRef]

[35] Heinz H, Pramanik C, Heinz O, Ding Y, Mishra RK, Marchon D, Flatt RJ, Lopis IE, lop J, Moya S, Ziolo RF. Nanoparticle decoration with surfactants: Molecular interactions, assembly, and applications. Surf Sci Rep. 2017; 72(1): 1-58. [CrossRef]

[36] Tojo C, Dios M, Barroso F. Surfactant effects on microemulsion-based nanoparticle synthesis. Materials. 2011; 4: 5572. [CrossRef]

[37] Anand K, Varghese S. Role of surfactants on the stability of nano-zinc oxide dispersions. Particul Sc1 Technol. 2017; 35(1): 67-70. [CrossRef]

[38] Morsy SM. Role of surfactants in nanotechnology and their applications. Int J Curr Microbiol App Sci. 2014;3(5): 237260

[39] Olbrich C, Bakowsky U, Lehr CM, Müller RH, Kneue C. Cationic solid-lipid nanoparticles can efficiently bind and transfect plasmid DNA. J Control Release. 2001; 77 (3): 345-355. [CrossRef]

[40] Gencer S, Cebeci A, Irmak-Yazicioglu MB. Silencing of the MMP-3 gene by siRNA transfection in gastric cancer AGS cells. J Gastrointestin Liver Dis. 2011; 20: 19-26.

This is an open access article which is publicly available on our journal's website under Institutional Repository at http://dspace.marmara.edu.tr. 